\title{
Instituições e desenvolvimento territorial: um estudo a partir do caso do arranjo produtivo de petróleo e gás natural localizado em Macaé-Brasil
}

Robson Dias. Instituto Federal Fluminense, Cabo Frio, Brasil.

\begin{abstract}
RESUMO | Nos últimos anos a abordagem institucional vem ganhando espaço nos estudos urbanos e regionais defendendo que, as normas, regras e convenções culturais devam ser levadas em conta nas pesquisas e políticas sobre o desenvolvimento territorial. Neste sentido, o objetivo deste trabalho é analisar, empiricamente, algumas implicações geradas pelas instituições na economia do arranjo produtivo de petróleo e gás natural de Macaé-Rio de Janeiro-Brasil. Durante a pesquisa verificou-se que as instituiçóes operam em diversas escalas, que na área de estudo pode-se segmentar em duas: normas de origem externa, que são impostas à escala local por agentes de grande poder de uso do espaço (o Estado e as grandes empresas) e as instituições de origem local, formadas a partir de reaçôes dos agentes locais às pressóes externas. A principal articulação ocorrida foi a Rede Petro-BC (Bacia de Campos), cuja análise é bastante sugestiva para a compreensão do ambiente institucional local.
\end{abstract}

PALAVRaS CHAVE | desenvolvimento regional e local, geografia econômica, teoria do desenvolvimento regional

ABSTRACT | In recent years the institutional approach has been gaining ground in urban and regional studies, defending that the norms, rules and cultural conventions should be taken into account in research and policies on territorial development. In this sense, the objective of this paper is to empirically examine some implications generated by the institutions in the economy of the productive arrangement of oil and natural gas in Macaé, Brazil. During the research it was found that the institutions operate at different scales, which in the study area can be segmented into two: external norms, which are imposed to the local level by agents with great power of usage of the space (the State and large companies) and institutions of local origin, formed from the reactions of local agents to external pressures. The main articulation was held by Rede Petro-BC, and its analysis is very suggestive to the understanding of the local institutional environment.

KEY WORDS | regional and local development, economic geography, regional development theory

Recibido el 5 de enero de 2011, aprobado el 22 de agosto de 2011

E-mail: robtata@gmail.com 


\section{Introdução}

A chamada "virada institucional" dos estudos urbanos e regionais tem dado algumas indicações originais sobre a relevância dos ambientes institucionais, formados pelo conjunto de regras formais e convenções culturais no delineamento, na trajetória e no desenvolvimento das economias regionais. Há, no entanto, poucos estudos empíricos que visem demonstrar essa relação, escassez esta proveniente de duas causas principais. A primeira é que trata-se de um enfoque relativamente recente, permeado de ambiguidades conceituais, já que o termo instituição é bastante polissêmico e utilizado por muitas correntes diferentes. A segunda, derivada da primeira, é que estudar a relação entre as instituições e o espaço econômico não é uma tarefa fácil no que se refere à metodologia. Dadas as imprecisões conceituais e as formas diversas vezes tácitas como as instituições operam na sociedade, identificar a influência destas é um desafio.

Apesar dessas dificuldades, o esforço da pesquisa se concentrou em dar forma a uma análise que ajude a explicar como, empiricamente, as instituições dão contornos à economia na escala local e quais perspectivas elas também geram para o desenvolvimento territorial. Dois critérios se tornaram relevantes na busca do método: i) os papéis dos agentes na criação, difusão e adaptação das instituições e ii) a interpenetração das diferentes escalas na conformação das instituições que organizam a esfera local.

A área de estudo é um caso emblemático. Macaé é um município que passou por um súbito crescimento econômico devido à rápida instalação e consolidação de um arranjo produtivo formado por empresas fornecedoras de produtos e serviços para as atividades extrativas de petróleo e gás natural na Bacia de Campos. Antes disso, Macaé era uma pequena cidade de pouca expressão, mesmo diante do contexto do empobrecido interior fluminense ${ }^{1}$. Após a instalação da base de apoio da estatal de petróleo brasileira, a Petrobras, Macaé se tornou o município mais dinâmico economicamente do Rio de Janeiro e um dos que mais cresceram no Brasil nas últimas duas décadas. Também conectou o município a lógicas que extrapolam, em muito, as relações de contiguidade, tornando-o mais sensível aos eventos que ocorrem em escala global e nacional.

A despeito da proeminência do arranjo produtivo de petróleo e gás natural de Macaé frente ao conjunto da economia estadual e mesmo nacional, a margem de manobra local é bastante limitada. A principal contradição é a própria forma invasiva como as empresas da cadeia produtiva de petróleo se instalaram no município, completamente alheias à trajetória histórica da economia regional. Isto dá um caráter exógeno às competências tecnológicas e gerenciais do setor em relação ao território, razão da qual a contradição entre o moderno e o tradicional se torna patente. O risco que se coloca nessa condição é a tendência ao enfraquecimento econômico, a partir do momento em que a produção de petróleo e gás natural da Bacia de Campos começar a decair. Mas há também potencialidades, que dependem do grau

1 Fluminense é o gentílico do estado do Rio de Janeiro. 
de internalização das competências setoriais pelas empresas e organizações que são mais enraizadas ao território local, caso principal das pequenas e médias empresas que emergiram no município pela expansão do arranjo produtivo.

FIGURA 1 Localização da área de estudo

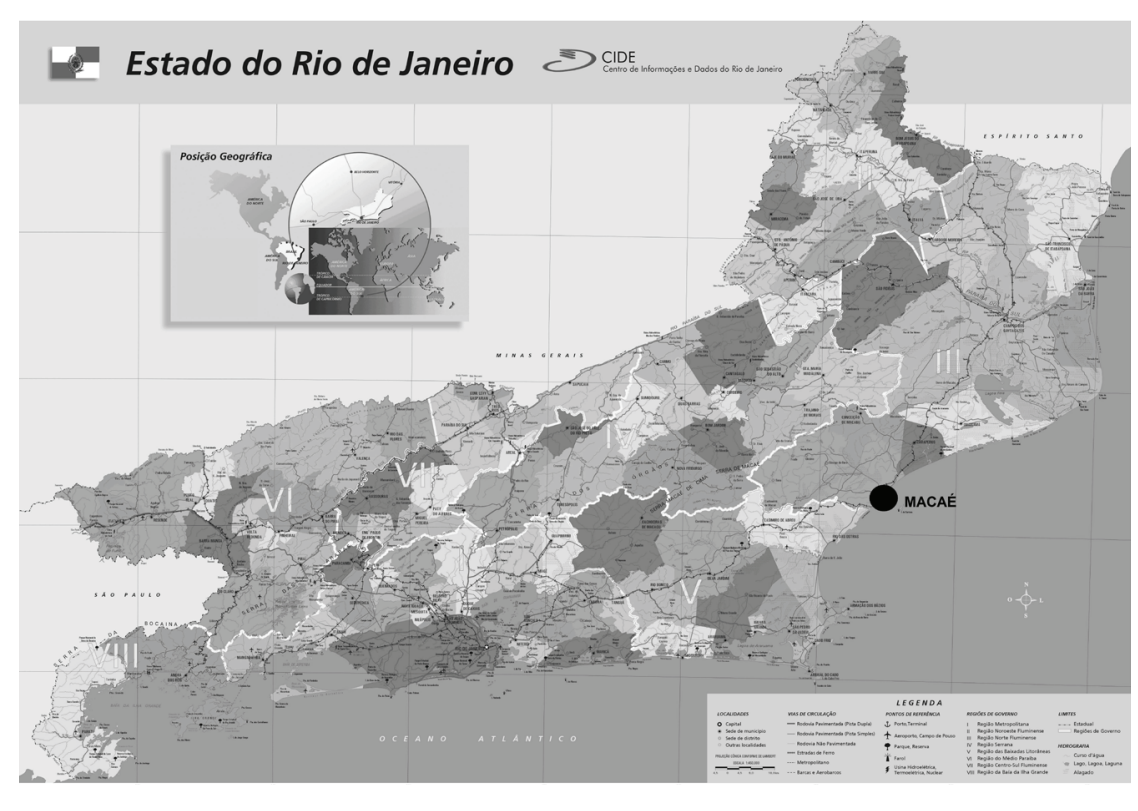

fonte Centro de Informaçốes e Dados do Rio de Janeiro.

Através da abordagem institucional é possível identificar alguns dos limites e das potencialidades mencionadas acima. Os principais agentes que impõem as normas que determinam a dinâmica setorial são de origem externa. As empresas petrolíferas, das quais a Petrobras é a principal, são todas multinacionais, assim como a maioria das grandes fornecedoras de bens e serviços. Destarte, as principais decisões, normas e competências tecnológicas são engendradas fora do âmbito local, nos centros de gestão e desenvolvimento tecnológico das empresas. Às empresas locais, cabe se adequar às exigências das grandes contratantes, que constituem a primeira e mais importante barreira de entrada à cadeia produtiva.

Há de se ressaltar também o papel do Estado, que regula as regras básicas da economia. No caso em estudo, o setor passou por importantes mudanças no marco regulatório, quando em 1997 o Estado brasileiro rompeu com o monopólio da exploração de petróleo e gás natural da Petrobras e abriu esse mercado ao investimento privado com o objetivo de aumentar a competitividade setorial. Com isso, se elevaram as dificuldades para as pequenas e médias empresas locais (e nacionais) entrarem nos concorridos contratos das principais empresas, o que aumentou o poder normativo das regras contratuais. 
No caso específico de Macaé, o contexto de ingerência normativa externa criou uma dupla realidade. Se por um lado, o aumento das pressões competitivas tem relegado a maioria das empresas locais à periferia da cadeia produtiva de petróleo e gás natural, por outro lado, as rígidas normas contratuais forçam-nas a adotarem posturas mais adequadas aos padrões setoriais. Foi diagnosticando essa dualidade da atual conjuntura que iniciativas locais vêm buscando criar estratégias de melhoria das competências das empresas. Dentre essas estratégias, a criação de redes de firmas tem se destacado, pressupondo que os pequenos e médios estabelecimentos necessitam atuar coletivamente para se inserirem em mercados dominados por grandes corporações. Assim, a questão relacional se impóe, pois o bom funcionamento das redes de empresas depende da criação de instituições que diminuam as incertezas e aumentem a confiança. Em Macaé esse papel tem sido desempenhado pela Rede Petro-BC (Bacia de Campos), que tem tentado conciliar a proximidade geográfica com a proximidade relacional.

$\mathrm{O}$ artigo está dividido em quatro partes. A primeira parte discorre sobre a Bacia de Campos, principal área produtora de petróleo e gás do Brasil, e sua importância na reestruturação econômica e territorial do estado do Rio de Janeiro, destacandose a formação do arranjo produtivo de petróleo e gás natural de Macaé. A segunda parte contém a fundamentação teórica que norteou a pesquisa. $\mathrm{O}$ conceito de "instituição" é discutido a partir de suas matrizes fundamentais, assim como sua adoção nos estudos urbanos e regionais. A terceira parte é dedicada à análise das instituições de origem externa que determinam a economia na escala local, respectivamente, a regulação do setor de petróleo e as normas de contratação da Petrobras, principal operadora da Bacia de Campos. Na quarta parte, faz-se uma avaliação da Rede Petro-BC como principal resultado das reações ocorridas na esfera local frente às imposições das instituiçôes externas e também alguns apontamentos sobre os entraves ao funcionamento da Rede Petro-BC e seu significado em relação ao ambiente institucional.

\section{A Bacia de Campos e o arranjo produtivo de petróleo e gás natural de Macaé: eixos da reestruturação econômico-territorial fluminense}

Em 2006 a Petrobras anuncia a conquista da autossuficiência na produção de petróleo no Brasil, pois com o início da operação das plataformas P-34 e P-50, o país passaria a exportar mais petróleo do que importava. Tal conquista não é importante apenas pelo fato de influenciar favoravelmente a balança comercial brasileira, mas principalmente como coroação do sucesso que se tornou o setor de petróleo e gás natural no país, haja vista que há trinta anos a produção petrolífera brasileira era insignificante. O anúncio, em 2007, das reservas gigantes na camada pré-sal da Bacia de Santos, consolida esse momento de auge, em que os olhos de todo o mundo se voltam para as promissoras províncias brasileiras, principalmente diante da redução das jazidas de tradicionais produtores como o México, os Estados Unidos 
e a Grã-Bretanha ou as incertezas políticas que sempre rondam o Oriente Médio. Para se chegar a esse momento, o papel desempenhado pela Bacia de Campos no crescimento e consolidação de um mercado petrolífero de porte no Brasil foi, e continua sendo, central.

Segundo Silvestre (2006), as atividades exploratórias na Bacia de Campos podem ser divididas em quatro etapas. A primeira começou em 1968 e se estendeu até 1974, quando foram feitas várias sondagens e perfurações com intuito de reconhecer o potencial da área. A segunda etapa é marcada pelo início das grandes descobertas, quando em 1974 foi identificado o primeiro poço com capacidade de uso comercial no campo de Garoupa, a 100 metros sob a lâmina d'água. A produção, no entanto, só começou em 1977 no campo de Enchova, o segundo descoberto, a 120 metros de lâmina d'água. Além destes, outros 27 campos foram descobertos, mas todos de pequena extensão. A terceira fase se iniciou em 1984 com a descoberta dos campos gigantes de Albacora (1984), Marlin (1985), Albacora Leste (1986) e Marlin Sul (1987) e outros 18 campos. Finalmente, a quarta fase se iniciou com a descoberta do campo gigante de Barracuda (1989), localizado em águas profundas. Outras importantes descobertas nesta fase foram os campos de Caratinga (1994), Espadarte (1994), Roncador (1996), Jubarte (2002) e Cachalote (2002).

FIGURA 2 Localização das áreas de exploração offshore

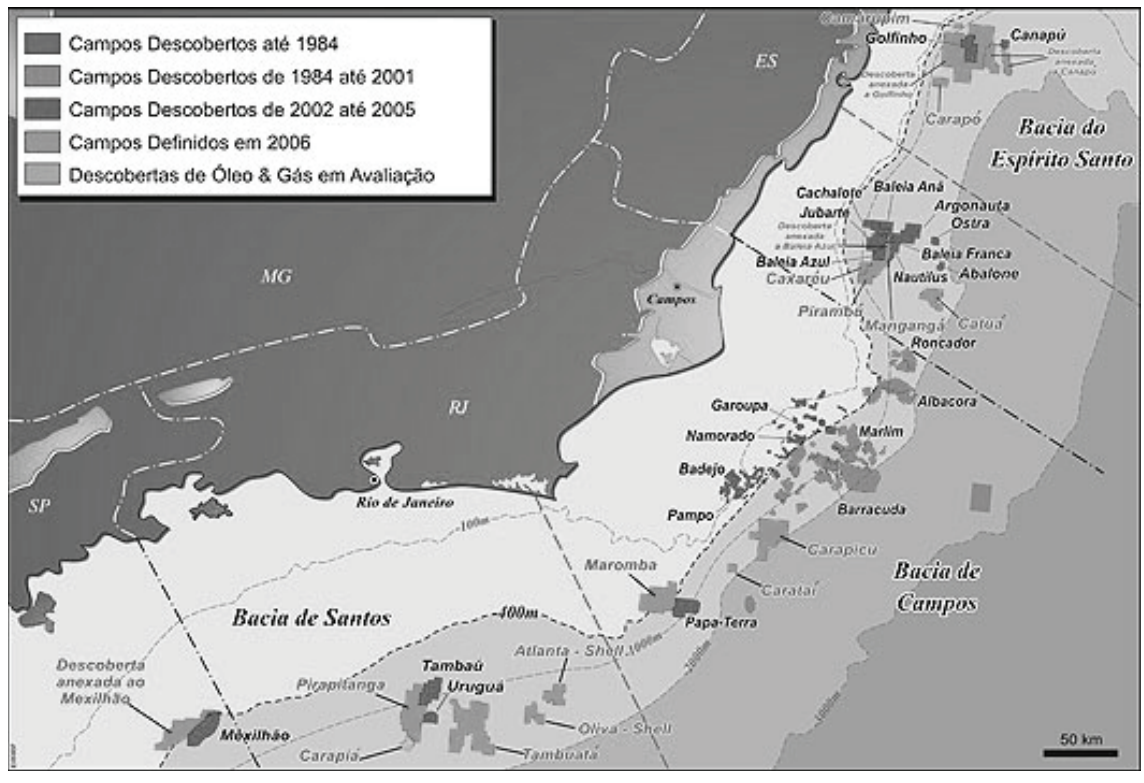

fonte Petrobras. 
Todas essas descobertas só foram possíveis graças ao imenso esforço da Petrobras em desenvolver tecnologias capazes de explorar os novos campos localizados em profundidades cada vez maiores. Silvestre (2006) observa que tal empreitada foi bem sucedida devido a projetos de pesquisa, desenvolvimento e qualificação da Petrobras, como o Programa de Desenvolvimento Tecnológico de Sistemas de Produção em Águas Profundas (Procap), desenvolvido em três versões (1986-1992, 1993-1999 e 2000 até a atualidade), que criaram competências para exploração nas profundidades de 1000, 2000 e 3000 metros, respectivamente.

Atualmente, a Bacia de Campos é a principal área de produção de petróleo e gás natural do Brasil e uma das maiores estruturas offshore do mundo. São 64 plataformas (fixas e flutuantes), 14 sistemas de produção flutuantes (FPS) e $4.400 \mathrm{~km}$ de redes de oleodutos e gasodutos e uma produção diária, em 2009, de 1.693 .575 barris de petróleo, o que equivale a $85 \%$ da produção total do Brasil. Segundo o site especializado Click Macaé, em 2004 o complexo da Bacia de Campos comportava cerca de 40 mil pessoas de várias partes do mundo, produzia um PIB de R 554 bilhões por ano, gerava cerca de $640 \mathrm{MW}$ de eletricidade (o suficiente para uma cidade de 1 milhão de habitantes), consumia cerca de 512 toneladas de alimentos e descartava 38 toneladas de lixo.

O rápido crescimento da exploração e produção de petróleo e gás na Bacia de Campos engendrou drásticas reestruturações na economia e no território fluminense. Em primeiro lugar, o setor de petróleo e gás natural foi o principal responsável pela retomada do crescimento da economia fluminense a partir de meados dos anos de 1990. Conforme demonstrou Dias da Silva (2004), desde a década de 20 do século XX, o Rio de Janeiro perdeu o posto de principal economia do Brasil para São Paulo. Desde então, a participação da economia fluminense na renda nacional foi diminuindo, enquanto que outros estados como Minas Gerais foram formando economias próximas ao porte do Rio de Janeiro. A crise da dívida brasileira, na década de 1980, foi um duro golpe para o Rio de Janeiro, uma vez que o consequente arrocho salarial imposto ao funcionalismo público federal, que segundo Natal (2004) tem cerca de $25 \%$ de seus quadros no estado, gerou fortes impactos na demanda interna do Rio de Janeiro. A crise foi de tal monta que entre 1985 e 1995 a economia fluminense cresceu apenas 7,5\%, muito abaixo do pífio crescimento do PIB brasileiro, que foi de 17,4\%. O grande aumento, porém, verificado em meados da década de 90 na produção de petróleo na Bacia de Campos coincide com a chamada inflexão positiva da economia do Rio de Janeiro, que entre 1995 e 2004 apresentou grande melhora, crescendo cerca de 30,4\%, significativamente superior ao crescimento da economia brasileira, de apenas 20,5\%. Foi um grande salto em relação ao desempenho do decênio anterior, puxado pela capacidade de alavancagem econômica da indústria de petróleo e gás.

Neste sentido, o setor de petróleo e gás natural tem sido o principal indutor, ainda que não o único, da reestruturação econômica e territorial em curso no estado do Rio de Janeiro. Novos investimentos vêm sendo atraídos pela atividade, 
dentre os quais se pode destacar os grandes projetos da termelétrica El Paso (US\$ 500 milhões) em Macaé (Norte Fluminense), do Porto do Açu (US\$ 1,6 bilhão) em São João da Barra (Norte Fluminense) e do Comperj (US\$ 8,4 bilhões), refinaria em construção em Itaboraí (Região Metropolitana do Rio de Janeiro). Há de se destacar, ainda, que os setores naval e químico também vêm sendo grandemente beneficiados pela expansão da atividade petrolífera no estado (Oliveira, 2003). Além disso, os orçamentos tanto do governo estadual quanto das prefeituras, principalmente dos municípios localizados na chamada Zona de Produção Principal, tornaram-se dependentes dos repasses de royalties e participações especiais referentes à Bacia de Campos². Devido ao enorme incremento das receitas municipais por tais recursos, o quadro de expansão de investimentos no interior do estado vem se intensificando, já que os municípios de Campos do Goytacazes, Macaé, Rio das Ostras e Quissamã têm financiado, com infraestruturas montadas ou mesmo empréstimos, a instalação de novas empresas em seus territórios.

O contexto de crescimento das atividades de exploração e produção de petróleo e gás natural na Bacia de Campos, por sua localização defronte ao litoral norte do estado, colocou a região no centro da interiorização da economia fluminense (Barral Neto \& Silva Neto, 2006). Além das receitas privilegiadas, os municípios costeiros do Norte Fluminense e das Baixadas Litorâneas tiveram uma significativa expansão de seus mercados de trabalho formal. Desconsiderando a Região Metropolitana do Rio de Janeiro (RMRJ), o Norte Fluminense se tornou a principal região empregadora, ultrapassando a industrializada região do Médio Paraíba, onde se localiza o município de Volta Redonda. A região das Baixadas Litorâneas, por sua vez, vem apresentando considerável crescimento da produção de empregos formais, sendo a segunda região de maior expansão do mercado de trabalho do estado (ver Gráfico 1).

A expansão do mercado de trabalho formal das regióes Norte Fluminense e Baixadas Litorâneas se deve, em grande parte, à localização do arranjo produtivo de petróleo e gás natural no município de Macaé. Este município era, até a década de 80 , pouco expressivo no contexto fluminense. Com a consolidação do município como principal base de apoio regional à exploração e produção da Bacia de Campos, Macaé se tornou a principal economia e principal gerador de empregos do interior do estado. Assim sendo, não é exagerado afirmar que a Macaé é o eixo propulsor da economia regional.

2 Os royalties e participações especiais são compensaçōes financeiras pagas pelas operadoras das jazidas de petróleo e gás natural ao governo federal, aos estados e municípios produtores. No caso da produção offshore, as receitas petroliferas são pagas aos estados e municípios costeiros cujas jazidas se situam defronte às suas áreas territoriais. Os municípios cujos territórios se projetam sobre as jazidas em alto mar formam a Zona de Produção Principal e são considerados produtores. Estes são os que recebem a maior parte dos repasses. Os municípios vizinhos à Zona de Produção Principal recebem através da categoria de regiōes geoeconômicas, que recebem influência indireta da exploração petrolífera. No Rio de Janeiro, os municípios que compõem a Zona de Produção Principal da Bacia de Campos são: São João da Barra, Campos dos Goytacazes, Quissamã, Carapebus, Macaé (todos pertencentes à região Norte Fluminense), Rio das Ostras, Casimiro de Abreu, Armação de Búzios e Cabo Frio (estes da região das Baixadas Litorâneas). Por conta das receitas petrolíferas, Carapebus, Quissamã, Macaé e Rio das Ostras estão entre os municípios de maior orçamento per capita do Brasil. 
O arranjo produtivo de petróleo e gás natural de Macaé começou a se estruturar com o início da produção de petróleo em escala comercial na Bacia de Campos. O município se tornou base das operações da Petrobras devido, principalmente, a alguns critérios locacionais clássicos: relativa proximidade do Rio de Janeiro, existência de um pequeno centro urbano que, mesmo sendo inadequado, era o que havia de melhor na região e, principalmente, a disponibilidade de uma área portuária na qual a Petrobras pudesse utilizar como apoio às plataformas em alto-mar. No entanto, segundo Nascimento (1999), Macaé não foi a primeira opção da empresa para montar sua base operacional. Como em São Mateus, no Espírito Santo, a Petrobras já possuía uma infraestrutura de exploração de petróleo em terra, Vitória acabou sendo o local preferencial da empresa para gerenciar a Bacia de Campos. Tendo em vista os conflitos entre a estatal e a prefeitura de Vitória sobre as condições de instalação de um porto para a empresa na cidade, a Petrobras desistiu de se estabelecer naquele município.

Grandes investimentos foram realizados pela empresa na região para montar a infraestrutura necessária para a produção de petróleo e gás na Bacia de Campos. Depois que a estatal começou a produzir no campo de Enchova em 1977, os investimentos da Petrobras em exploração e produção tiveram um repentino crescimento, quando passaram de US\$ 656 milhões em 1977 para US\$ 1, 04 bilhão em 1979, sendo somados apenas US\$ 186 milhões em 1973. É razoável supor que parte desse investimento crescente fora destinada para Macaé na montagem da Unidade Operacional da Bacia de Campos. Assim, a expansão das atividades na Bacia de Campos alavancava o crescimento do arranjo produtivo de petróleo e gás natural de Macaé, que atualmente é a maior concentração de empresas do setor no país. O quadro 1 demonstra com base no cálculo do quociente locacional ${ }^{3}$, que o município de Macaé se tornou altamente especializado em diversas atividades relacionadas ao segmento upstream da cadeia produtiva de petróleo e gás natural, principalmente na extração de petróleo e gás e atividades de apoio à extração de petróleo e gás. Essas atividades representam, ainda, $36 \%$ do mercado de trabalho local.

Entre 1985 e 2007, o número de estabelecimentos no município quadruplicou. Há, no entanto, uma diferença no tocante à dinâmica verificada no restante do Brasil. No mesmo período verificado, o número de estabelecimentos no país também aumentou, porém com o detalhe de que o porte médio das empresas em termos de número de empregados tendeu à diminuição, apontando para um processo de desintegração produtiva no país. No caso de Macaé, entre 1985 e 1995, a tendência foi semelhante à brasileira, porém, após meados da década de 90 , a tendência foi o aumento do porte médio dos estabelecimentos (Quadro 2). Isto indica uma maior atratividade de empresas para o município, certamente uma consequência da abertura do setor petrolífero brasileiro ao investimento privado em 1997.

3 Quociente locacional é uma pequena equação em que se divide o número de empregos de um setor $x$ de um município $z$ pelo total de empregos do município $z$. Posteriormente, se divide o resultado pela divisão do total de empregos do setor $x$ no Brasil, dividido pelo total de empregos do Brasil ( $\{$ EMPxz / EMPz / \{EMPx BR / EMP BR \}). Quando o QL for igual a 1, seu grau de especialização é igual à média brasileira; quando for maior que 1, o grau de especialização é superior à média brasileira e se for menor que 1 , sua especialização é menor que a média brasileira. 
GRÁFICo 1 Distribuição dos empregos entre as regiôes fluminenses (exceto a RMRJ)

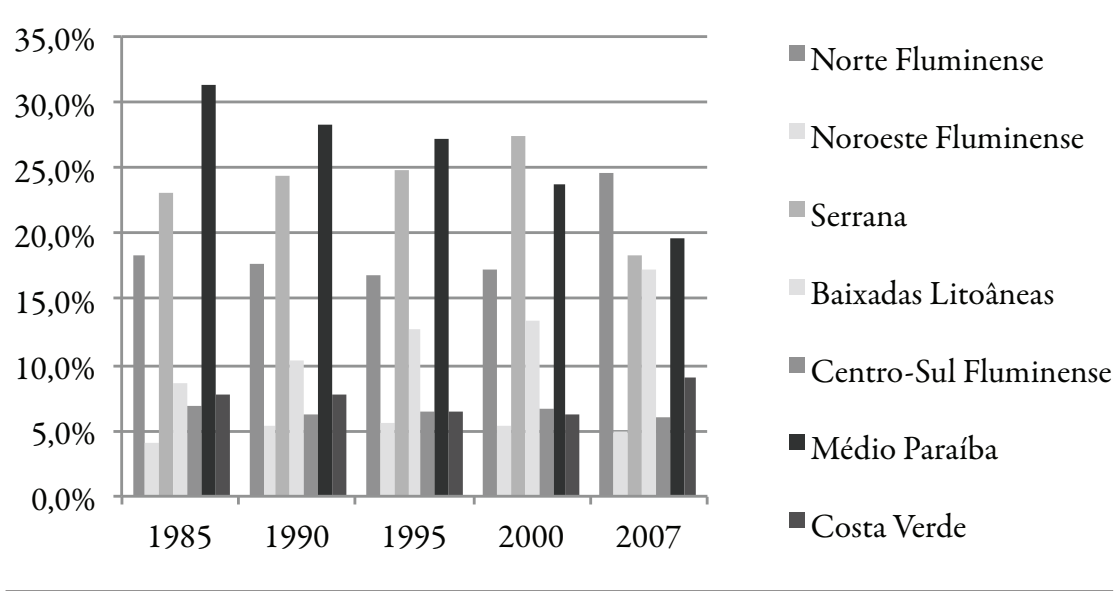

fonte Relatório Anual de InformaÇóes Sociais - Ministério do Trabalho e do Emprego (RAIS-MTE).

QUADRO 1 Especialização produtiva do município de Macaé em 2006

\begin{tabular}{|c|c|c|c|}
\hline $\begin{array}{l}\text { GRUPO DE ATIVIDADE ECONÔMICA, SEGUNDO } \\
\text { CLASSIFICAÇÃO CNAE - VERSÃO } 2.0\end{array}$ & EMP. 2006 & QL MACAÉ & $\mathrm{PR}$ \\
\hline Extração de petróleo e gás natural & 11.613 & 204,54 & $49,6 \%$ \\
\hline Atividades de apoio à extração de petróleo e gás natural & 6.759 & 99,81 & $24,2 \%$ \\
\hline $\begin{array}{l}\text { Fabricação de máquinas e equipamentos de uso na } \\
\text { extração mineral e na construção }\end{array}$ & 2.013 & 46,78 & $11,4 \%$ \\
\hline Transporte marítimo de cabotagem e longo curso & 984 & 44,67 & $10,8 \%$ \\
\hline Navegação de apoio & 129 & 27,73 & $6,7 \%$ \\
\hline Testes e análises técnicas & 396 & 16,15 & $3,9 \%$ \\
\hline Construção de outras obras de infra estrutura & 4.717 & 9,23 & $2,2 \%$ \\
\hline Atividades auxiliares dos transportes aquaviários & 507 & 7,36 & $1,8 \%$ \\
\hline $\begin{array}{l}\text { Serviços de catering, bufê e outros serviços de comida } \\
\text { preparada }\end{array}$ & 2.603 & 6,43 & $1,6 \%$ \\
\hline $\begin{array}{l}\text { Fabricação de estruturas metálicas e obras de caldeiraria } \\
\text { pesada }\end{array}$ & 1.355 & 6,12 & $1,5 \%$ \\
\hline
\end{tabular}

FONTE ELABORADO A PARTIR DE DADOS DO RAIS-MTE.

${ }^{*}$ QUOCIENTE LOCACIONAL | ${ }^{* *}$ PARTICIPAÇÃo RELATIVA. 
QUADRO 2 Número e porte médio dos estabelecimentos em Macaé

\begin{tabular}{l|lcccc}
\multicolumn{7}{l}{ ESTABELECIMENTOS MACAÉ 1985-2007 } \\
\hline & 1985 & 1990 & 1995 & 2000 & 2007 \\
\hline & 924 & 2.578 & 1.827 & 2.487 & 3.751 \\
$\begin{array}{l}\text { Número de } \\
\text { Estabelecimentos }\end{array}$ & 19,8 & 17,5 & 12,4 & 15,3 & 24,8 \\
Tamanho médio & & & & & \\
\hline
\end{tabular}

FONTE RAIS-MTE.

Em termos de mercado de trabalho, o município de Macaé divide com Campos dos Goytacazes o posto de principal município empregador do interior fluminense (Gráfico 2), apesar de possuir apenas menos da metade da população do segundo. Certamente, a aceleração na produção de empregos formais no Norte Fluminense foi o principal indutor do crescimento da empregabilidade dos municípios vizinhos, tanto do Norte Fluminense quanto das Baixadas Litorâneas. Macaé se tornou um centro de convergência de imigrantes à procura de emprego. Muitos dos novos habitantes optam por morar em municípios vizinhos, o que torna o fenômeno da população flutuante um importante fator da dinâmica demográfica municipal. De qualquer modo, o município passou por um salto populacional nos últimos 30 anos. Entre 1991 e 2007, a população residente passou de aproximadamente 93 mil para 169 mil habitantes, ou seja, uma taxa superior a $4 \%$ ao ano.

GRÁfICO 2 Evolução de Empregos Formais em Macaé: 1985-2009

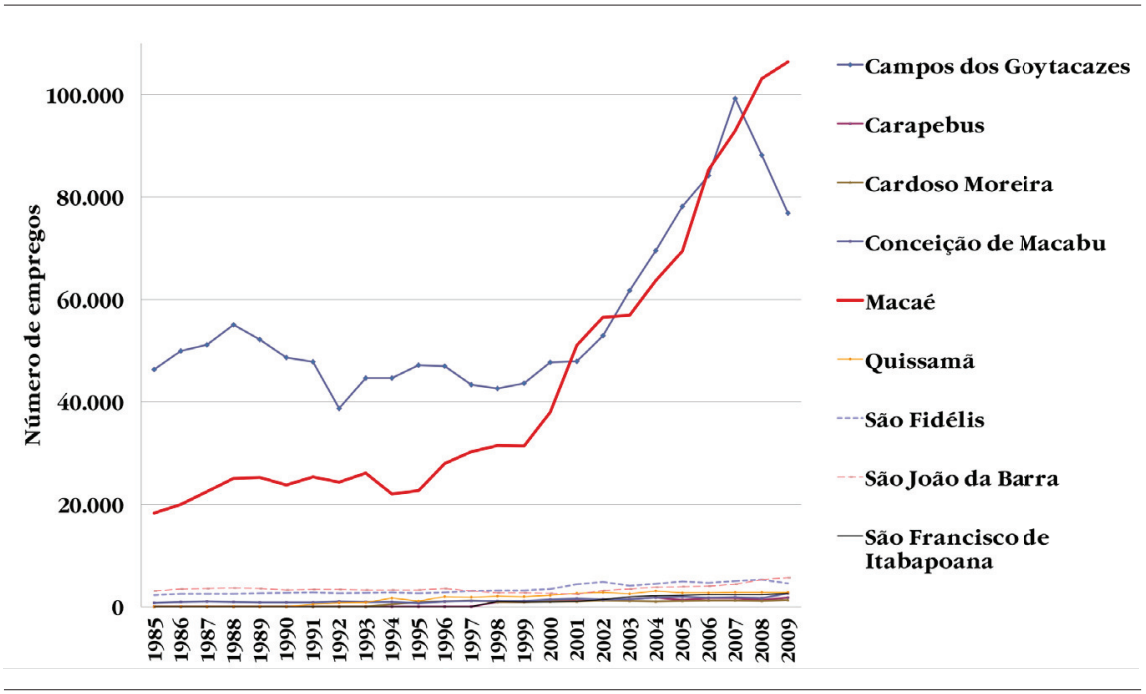

FONTE ELABORADO A PARTIR DE DADOS DO RAIS-MTE. 
Está demonstrado, portanto, que a consolidação das atividades de exploração e produção de petróleo e gás natural determinou profundas transformações territoriais, econômicas e sociais no Rio de Janeiro, projetando o município de Macaé a uma posição de destaque nos cenários regional e nacional. A despeito do grande crescimento econômico verificado localmente, deve-se ressaltar que o período também foi marcado pelo surgimento e recrudescimento de inúmeros problemas que relativizam o mito do crescimento acelerado. Como mencionado, o município vem passando por um rápido processo de crescimento populacional, engendrado pela atratividade empregatícia da concentração de empresas do setor petrolífero. Notadamente, o crescimento demográfico macaense vem se concentrando especificamente na área urbana do município, cuja demanda imobiliária vem pressionando a incorporação de novas áreas para fins de locação empresarial ou habitacional. A cidade, no entanto, sofre de uma crônica saturação dos serviços e infraestrutura urbana, apresentando, há muito tempo, problemas similares aos das grandes cidades, tais quais, congestionamentos das vias de circulação, inflação geral dos preços (da terra em particular), favelização, etc.

A favelização tem sido uma das consequências mais conspícuas do atual período. Como é comum nas áreas de pujança econômica na América Latina, grande parte dos fluxos migratórios é composta por indivíduos incapazes de se inserirem no competitivo mercado formal de trabalho. A consequência lógica é a formação de uma cidade fragmentada entre uma minoria, que aufere altos ganhos a partir dos encadeamentos gerados pela economia petrolífera, e uma maioria que, excluída dos empregos de altos salários, luta pela sobrevivência em segmentos marginais da economia urbana. Tal situação pode ser considerada uma sequela direta da hegemonia do segmento petrolífero, pela simples razão de que toda atividade que em maior ou menor grau não tenha sido impulsionada pelo setor petrolífero foi relegado ao ostracismo econômico e social. De outra maneira, por conta da inflação geral dos preços, os indivíduos ocupados nas atividades marginais foram forçados a sobreviver em condições de precariedade nas cada vez maiores "áreas informais" da cidade. Há de se ressaltar que, com a política recente de enfrentamento ao tráfico de drogas na cidade do Rio de Janeiro, as favelas de Macaé se tornaram muito atrativas para os criminosos expulsos das favelas cariocas, aumentando a insegurança dos moradores dos bairros empobrecidos da cidade. Apesar do recrudescimento desse fenômeno, é ponto pacífico que o crescimento das atividades do tráfico de drogas no município vem sendo estimulado há mais tempo pela constituição de um mercado consumidor de alta renda na região.

A formação do arranjo produtivo representou, ainda, um notório desgaste do meio ambiente local e regional. O crescimento econômico e a urbanização vêm pressionando crescentemente os recursos hídricos e as áreas de cobertura vegetal, gerando um quadro de insalubridade no meio urbano local. Via de regra, as áreas favelizadas ocuparam principalmente as encostas de morros, margens de mananciais e manguezais, qual seja, zonas de alta vulnerabilidade ambiental. Da mesma forma, empreendimentos de alta renda ou para fins empresariais vêm se destacando 
por seu alto grau de impacto ambiental. Mas como de práxis, nestes casos as administrações públicas são mais eficientes em empreender ações mitigadoras, enquanto que no primeiro caso, existe certa letargia em atenuar os passivos socioambientais.

Qual seja, nota-se que a pujança econômica engendrada a partir da formação do arranjo produtivo de petróleo e gás natural foi acompanhada de uma série de contradições socioambientais nada desprezíveis, advindas da mesma matriz que possibilitou a fase de prosperidade. Talvez, e justamente por advirem do mesmo processo que alçou o município às altas taxas de crescimento econômico, essas contradições são tratadas pelos órgãos governamentais de forma apenas parcial e insuficiente. Pela parte das empresas, mesmo com a generalização de certo espírito "politicamente correto" que recomenda a promoção de ações de responsabilidade social e ambiental predomina, como seria de se esperar, a estreita visão de curto prazo, vis a vis com as conjunturas e janelas de oportunidades que surgem no setor petrolífero. Mesmo nas iniciativas de internalização das competências setoriais como a Rede Petro-BC, o horizonte estratégico de ação segue apenas o viés econômico e setorial. Não é o foco deste trabalho tratar essas questões que "saltam à vista" do observador atento, mas vale destacar que são problemáticas sempre presentes nos debates sobre as regiões petrolíferas, tendo em vista a finitude do recurso fóssil.

Uma rápida análise comparativa entre diferentes cidades petrolíferas aponta para um inexorável quadro de queda dos fluxos de riqueza quando a produção dos campos petrolíferos entra em fase de maturidade. Por isso, a reflexão sobre as alternativas econômicas para o período pós-petróleo é fundamental. Borba e Silva Neto (2008) demonstram que no caso de Aberdeen na Escócia o projeto construído para a era pós-petróleo está alicerçada na transformação das competências da indústria petrolífera em competências no desenvolvimento de tecnologias energéticas renováveis, como a eólica. Para tanto, tem-se investido pesadamente em pesquisas e inovação tecnológica a partir do conhecimento adquirido durante o boom petrolífero, o que nos remete novamente à questão institucional: a criação de sinergias entre os diferentes atores locais no sentido de um projeto coletivo de desenvolvimento territorial. Em casos em que essas institucionalidades não são criadas, sobram os passivos negativos do setor petrolífero, tão fortes principalmente nas regiões periféricas do capitalismo.

$\mathrm{O}$ que se quer apontar é que no bojo da própria estrutura econômica que fundamenta a existência do arranjo produtivo de Macaé existem gargalos limitantes, os quais são escamoteados pelo fluxo cotidiano das atividades econômicas do setor. São para essas questões que a pesquisa buscou apontar possíveis alternativas.

Em primeiro lugar, as principais empresas que compõem o arranjo produtivo são meras sucursais operacionais das multinacionais cujas inovações são produzidas em outras localidades do Brasil e do mundo. De outra maneira, o arranjo produtivo de Macaé se situa no final da cadeia de valor do segmento upstream da indústria de petróleo. A maior parte das pequenas e médias empresas sediadas no município ou na região atua, ou no comércio de produtos industriais, ou na prestação de serviços especializados. A participação de empresas industriais no arranjo produtivo é mí- 
nima. Existe um potencial econômico a ser explorado pelas pequenas e médias empresas na internalização das competências específicas do setor petrolífero porém, na situação atual, não se verifica força suficiente para sua sustentação econômica fora dos limites projetados pelas demandas locais das grandes empresas.

Em segundo lugar, não obstante a intensidade de fluxos mercantis no interior do arranjo produtivo, verifica-se um pequeno aproveitamento das oportunidades de internalização de novas competências, devido ao considerável desinteresse do tecido empresarial local em apoiar efetivamente projetos coletivos que promovam o desenvolvimento local. Em pesquisas desenvolvidas por Piquet e Oliveira (2007), Fauré (2005) e Oliveira (2005), constata-se que a classe empresarial local, tanto das grandes empresas quanto das pequenas e médias, possuem uma relação meramente instrumental com o território, demonstrada pelas exigências de políticas públicas que apenas mantenham a infraestrutura física adequada para as operações cotidianas. Além disso, há uma notória desconfiança em relação a qualquer tipo de organização ou projeto que empreenda ações de natureza mais estrutural, sendo, portanto, o isolamento e a atomização dos agentes um dos gargalos mais fundamentais no arranjo produtivo.

O corolário é o não aproveitamento da proximidade geográfica como matriz para a formação de sinergias, que melhorem os ambientes relacionais e permitam a internalização de novas competências, a partir dos fluxos de conhecimentos e informações estratégicas que, diariamente, circulam pelo território local.

Tendo em vista, portanto, o quadro que caracteriza estruturalmente a atual conjuntura do arranjo produtivo de petróleo e gás natural de Macaé, a questão que se levanta é: quais alternativas existem para a promoção do desenvolvimento territorial a partir da conjunção das potencialidades e limites observados na esfera local? A opção teórica pelo institucionalismo se justifica pelo fato da problemática esboçada perpassar, prioritariamente, pela dimensão institucional. No caso, foi a partir de mudanças institucionais a nível nacional que se determinou a trajetória econômica local na última década. Além disso, a questão da internalização das competências setoriais pelas empresas locais se inicia a partir da adequação aos padrões normativos que orientam o mercado de contratações, assim como revela a imperiosidade da transformação de hábitos profundamente arraigados na prática empresarial local.

\section{A abordagem institucional: uma alternativa para pensar o desenvolvimento territorial}

A abordagem institucional tem ganhado espaço nos meios acadêmicos nos últimos anos. No âmbito da economia, o temário institucional alcançou muita projeção com o brilho de laureados pelo Nobel, como Ronald Coase, Douglas North e Oliver Williamson, alguns dos principais divulgadores da Nova Economia Institucional (NEI). Há, porém, uma diversidade de correntes que se incumbem em estudar a economia pelo viés das instituições. Os precursores foram os intelectuais da chamada Escola Histórica Alemã, ainda no século XIX. Nos Estados Unidos, 
coube à Thorstein Veblen a tarefa de iniciar a análise institucional da economia, criando com isso, o Institucionalismo Norte Americano. Ambas as correntes são identificadas pela sua perspectiva historicista, dando valor às convenções sociais, culturais e legais que determinam o funcionamento dos sistemas econômicos, ou seja, tentando entender como a economia funciona em sua concretude histórica. Era uma perspectiva contrária ao nascente Marginalismo que, fiel ao positivismo, concebia modelos teóricos ideais de funcionamento da economia, de modo a permitir a elaboração de leis gerais e subsidiar a capacidade de previsão das flutuações econômicas. A partir da década de 30 do século XX, no entanto, o institucionalismo perde espaço para seu concorrente, que se torna, deste modo, a corrente principal (mainstream) do pensamento econômico.

A partir da década de 70, observa-se o retorno do temário institucional, sob o título de Novo Institucionalismo que engloba, porém, diversas correntes de pensamento. Algumas resgatam a perspectiva iniciada por Veblen, porém a mais influente é, sem dúvida, a NEI, também conhecida pelo rótulo Institucionalismo da Escolha Racional. O precursor da NEI foi Ronald Coase, que em 1937 publica um artigo lançando o conceito de custo de transação, para ele determinante para a existência da firma e, em 1960, publica outro artigo analisando o problema da interferência dos custos sociais (custos de transação) na alocação de recursos na economia. Posteriormente, os autores da NEI procuram entender o que faz as transações nas economias ocidentais avançadas serem mais eficientes do que em outras partes do mundo. Suas pesquisas apontavam que as instituições determinam os custos de transação, logo, aumentando ou diminuindo a eficiência das economias.

Tendo em vista a variedade de abordagens, o conceito de instituições acabou se tornando muito ambíguo, tanto mais pela adoção do termo na linguagem cotidiana. Neste trabalho, adotou-se a definição feita por North (1990) que, apesar de ser um dos expoentes da NEI, apresenta um bom grau de generalização. Neste sentido, as instituições seriam o conjunto de regras e normas que modelam a forma que os indivíduos interagem numa dada sociedade. Tais regras possuem caráter diverso, englobando tanto regras formais quanto informais. Assim, a legislação, os contratos, as organizações (Estado, empresas, organizações da sociedade civil), as sanções, os direitos de propriedade e as normas culturais de comportamento, seriam alguns dos componentes que formam os ambientes institucionais que referenciam as formas como as economias vão se desenvolver. As raízes do desenvolvimento econômico desigual, entre países e regiôes, ao longo da história do capitalismo seriam assim, melhor compreendidas.

A ascensão das novas abordagens institucionalistas coincide com o processo de reestruturação produtiva e de globalização da economia, deflagradas após o primeiro choque do petróleo em $1973^{4}$. A crise do modelo de Estado intervencionista e da

4 Esse evento é citado como marco referencial e não como data de início da reestruturação produtiva, visto que muitos processos que engendraram a crise ou que se tornaram hegemônicos durante o último quartel do século XX, possuem origens muito anteriores à década de 70 . 
indústria taylorista-fordista, que sustentaram a expansão econômica nas duas décadas posteriores ao fim da Segunda Guerra, deflagrou um poderoso processo de reestruturação territorial da produção. Segundo aponta Scott (1988), os tradicionais complexos industriais fordistas começaram a sofrer com o esvaziamento econômico gerado pela relocalização das plantas fabris. Ao mesmo tempo, novos espaços industriais emergiram baseados em modelos organizacionais flexíveis, geralmente ligados aos setores de alta tecnologia ou mesmo da indústria tradicional (de bens duráveis e não duráveis) que fizeram da inovação uma rotina. Os paradigmas de planejamento territorial, fundados no padrão espacial fordista mostraram-se insuficientes para conter o quadro de aumento do poder de uso do espaço pelas empresas multinacionais. As políticas neoliberais, por outro lado, mostraram-se desastrosas, já que a abertura e a exposição dos territórios às forças de mercado, sem a mediação do Estado, exacerbou as disparidades territoriais (AMIN, 1999).

Em reação a esse contexto de esgotamento paradigmático e de crise econômica, desde fins da década de 70 se inicia a elaboração de novas formas de pensar a teoria do desenvolvimento territorial. As políticas de desenvolvimento regional centralizadas, operacionalizadas nos polos de crescimento, por exemplo, dão lugar às políticas de desenvolvimento "a partir de baixo", ou seja, aproveitando as potencialidades endógenas dos territórios, estes cada vez mais associados à escala local. Num primeiro momento, o modelo seguido foi o Vale do Silício californiano, que inspirou a criação dos chamados tecnopolos. Com o arrefecimento do entusiasmo em torno dos tecnopolos, em grande parte devido à dificuldade de um tecnopolo se tornar realmente um centro de inovação tecnológica de ponta, pelo menos na escala temporal exigida na lógica capitalística, uma nova panaceia tomou forma, tendo como referencial os distritos industriais italianos. Neste paradigma, ocorreu de forma melhor acabada a "endogeneização" da teoria do desenvolvimento territorial. Tal concepção foi reforçada com a difusão do conceito de capital social, cujo objeto empírico foi também a Itália ${ }^{5}$. As novas concepções de desenvolvimento territorial passaram a utilizar o conceito de território não mais como substrato físico das atividades econômicas, mas como uma entidade geográfica conformada por um mix de produção, meio social e traços culturais específicos, que interagem a favor ou contra o desenvolvimento econômico.

No caso brasileiro, particularmente, essa abordagem ganhou força com o desenvolvimento do conceito de arranjo produtivo local, uma variante dos distritos industriais para a realidade da economia brasileira. Na última década, principalmente, o incentivo aos arranjos produtivos locais tornou-se a ação de referência para as políticas de desenvolvimento territorial empreendidos pelos órgãos governamentais do país, em substituição à antiga política regional a la SUDENE e suas

5 Segundo Putnam (2006, p. 177), "o capital social diz respeito a características da organização social, como confiança, normas e sistemas que contribuam para aumentar a eficiência da sociedade." Cabe notar que a noção de capital social desenvolvida por Putnam referencia-se, em grande medida, no neoinstitucionalismo. 
congêneres ${ }^{6}$. Assim, a escala local tornou-se importante para o próprio desenvolvimento nacional, visto que as políticas dos arranjos produtivos locais fazem parte atualmente tanto do Plano Nacional de Desenvolvimento Regional, quanto dos programas de financiamento do Banco Nacional de Desenvolvimento Econômico e Social (BNDES).

Fundamentalmente, o atual debate a respeito do desenvolvimento territorial gira em torno da pergunta se a proximidade geográfica continua sendo relevante diante das novas possibilidades de contato geradas pelas tecnologias de informação e comunicação e do aumento da flexibilidade locacional, verificado em muitos setores da economia. Alguns autores, como é o caso de Scott (1988), creditam à desintegração e flexibilização da produção, a força de atração da contiguidade espacial, visto que a formação de uma aglomeração de empresas especializadas de uma mesma cadeia produtiva ajuda a diminuir os custos de transação na relação insumoproduto, além de atrair os fluxos de mão de obra qualificada. Trata-se, na verdade, de uma retomada das externalidades marshalianas, o que explica o renovado prestígio alcançado pelo economista Alfred Marshall. Posteriormente, porém, tal abordagem foi considerada insuficiente pois, como afirmou Veltz (1999), devemse diferenciar os processos de territorialização em que as atividades econômicas se tornam dependentes de recursos específicos gerados pela proximidade geográfica, dos processos de simples localização, que apesar de aproveitar as economias de aglomeração, não geram competências localizadas intransferíveis para outros lugares. Esta é a situação, por exemplo, de inúmeras concentrações produtivas existentes no Brasil que, segundo Santos et al (2006), possuem muitos problemas de competitividade justamente por não gerarem benefícios a partir da proximidade geográfica.

A contribuição da abordagem institucional está no seu enfoque nas chamadas "interdependências não mercantis", apontadas por Storper (1997) como fatores que transformam o território em recurso econômico. Para Amin (2001), devemse levar em conta os hábitos passados, as rotinas, o conhecimento, a capacidade cognitiva, as relações intersubjetivas, o poder corporativo, a regulação e as políticas governamentais e não governamentais. Hayter (2004) demonstra que esse enfoque descreve uma economia social do território, o que alimenta conceitualmente a nova concepção de desenvolvimento territorial.

Desse modo, a própria delimitação dos espaços econômicos é feita a partir de sua institucionalidade. Para Martin (2000), tais espaços são constituídos a partir da relação entre o que ele denomina "arranjo institucional", formado pelas organizações específicas que são os agentes da economia (Estado, empresas, sindicatos etc.) e o "ambiente institucional", o qual contempla tanto o conjunto de normas sociais quanto as estruturas de regras e regulamentaçóes legais que demarcam o comportamento econômico. No caso, um e outro são mutuamente condicionados, visto

6 No caso, a referência é à SUDENE (Superintendência do Desenvolvimento do Nordeste), dentro da perspectiva cepalina das décadas de 50, 60 e 70, e não à nova SUDENE, implantada recentemente no governo Lula. A SUDENE "original" foi associada à ideologia desenvolvimentista, que preconizava o dirigismo do Estado na economia. Nesta perspectiva, cabia ao Estado resolver o problema do desenvolvimento desigual, que se manifestava no Brasil na diferença entre o Centro-Sul industrializado e as demais grandes regiōes brasileiras, particularmente o Nordeste. 
que os arranjos institucionais se formam de acordo com o ambiente institucional pré-existente, assim como os ambientes institucionais evoluem de acordo com a ação dos arranjos institucionais. ${ }^{7}$ Batista (2006) chega a uma conclusão semelhante ao construir a conceituação de território produtivo. Este, de acordo com a autora, se estrutura sobre três pilares: a dimensão institucional (ou ambiente institucional), a dimensão técnico-produtiva (ou arranjo institucional) e a dimensão espacial (a aglomeração de atividades).

Com efeito, a abordagem institucionalista tem sido apontada como uma "terceira via" para as políticas de desenvolvimento do território, em substituição das concepções keynesianas e neoliberais (Amin, 1999). Ao contrário de suas concorrentes, ela não propõe uma teoria geral do desenvolvimento. Fiel às suas origens historicistas, a abordagem institucional visa compreender contextualmente as potencialidades e os limites que se colocam frente aos territórios, o que em termos de políticas de ação, significa identificar o conjunto de normas formais e informais condicionantes do comportamento econômico, assim como os agentes capazes de modificar essas normas, arbitrariamente ou não.

Para os propósitos deste trabalho, destacam-se duas questôes que são importantes para compreender como as instituições interferem na trajetória econômica dos territórios. Primeiro, quem são os agentes que criam as normas que modificam os ambientes institucionais e quais são suas escalas de origem? Segundo, de que forma os agentes territorializados (incapazes de desvincularem-se totalmente de seus locais de origem) podem transformar a proximidade geográfica num recurso específico.

Quanto ao primeiro ponto, a proposição de Santos (2004) sobre os dois arranjos espaciais no mundo contemporâneo, as horizontalidades e as verticalidades, traz alguns insights interessantes. Para o autor, a globalização é viabilizada a partir da hierarquia organizacional característica das redes, que impóem as mesmas lógicas a lugares espacialmente descontínuos. Tais lógicas são institucionais, pois elas normatizam as ações que operam sobre o território. Elas, no entanto, possuem pontos de origem, cuja influência depende do poder de uso do espaço que as redes organizacionais possuem. $\mathrm{O}$ caso das multinacionais é clássico. Nos tempos atuais, as grandes corporações multinacionais possuem um raio de ação global de produção e distribuição, o que só é possível pela lógica reticular. As estratégias corporativas, no entanto, são privilégio de algumas poucas unidades gestoras, geralmente localizadas nas chamadas cidades globais. É a partir delas que as normas são criadas e difundidas por toda sua estrutura organizacional que, com o processo de desintegração produtiva das últimas décadas, estende a influência normativa dos centros gestores para inúmeras empresas terceirizadas por cada unidade das corporações. O papel do Estado não pode ser esquecido, pois sua função legislativa impõe as regras do jogo para toda a sociedade imersa ao seu território, ora reforçando, ora competindo com as regras impostas pelas grandes empresas.

Há, porém, as lógicas das horizontalidades, em que Santos (2004) lança seu

7 É digno de nota que o termo "arranjo institucional" é também alvo de ambiguidades. Por isso, ressalta-se que a utilização neste texto é de acordo com a definição dada por Martin (2000). 
olhar para os espaços da contiguidade, lócus da vivência das pessoas em toda a sua diversidade. São nesses locais que as redes globais instalam suas instituições verticais, gerando tanto acomodações às imposições normativas, quanto resistências a elas. Ambas são sinais de profundas reestruturações socioespaciais engendradas pelas verticalidades, como acontece no caso em estudo neste trabalho. Para Hayter (2004), são essas contradições entre as instituições externas impostas ao território e as reações locais engendradas que originam a diferenciação regional no mundo globalizado. É através desse mecanismo que as interdependências não mercantis, discutidas por Storper (1997), podem gerar recursos específicos no território, em oposição às tendências homogeneizadoras das redes.

A segunda questão é, como já foi comentado, a principal problemática para as políticas de desenvolvimento territorial a nível local ou regional. Não se trata de uma equação de fácil resolução, principalmente nos espaços periféricos. Estar próximo geograficamente não significa que há proximidade relacional. Autores como Fillipi e Torre (2002) e Rallet (2002) são bastante enfáticos ao diferenciar a proximidade geográfica da proximidade relacional. No caso, a proximidade relacional se forma pelas relações construídas segundo as lógicas da similitude e do pertencimento, que podem se formar dentro de uma mesma organização, de um setor produtivo ou de um território. A proximidade geográfica pode potencializar a aproximação relacional, sincronia esta que é o grande objetivo e o maior gargalo na implantação de políticas que estimulem o desenvolvimento local e regional. É neste sentido que Storper (1997) não hesita em afirmar que nestes tempos de economia globalizada, a região torna-se um bem relacional.

O ambiente institucional é um dos aspectos que explicam se a proximidade geográfica incentivará ou não a proximidade relacional. A literatura especializada tende a apontar que na economia hodierna, cujo motor está apoiado no conhecimento e na inovação, um ambiente que favoreça o aprendizado é uma vantagem comparativa importante. No entanto, não se trata de um aprendizado isolado, mas sim um esforço coletivo. Os fluxos locais de informação e conhecimento se tornam mais facilitados se mediados por instituições que reduzam as incertezas, dentre as quais pode se destacar-se o oportunismo. Há também a questão do conhecimento tácito, não codificado, que só é decifrado e difundido quando os agentes compartilham de um mesmo sistema de convenções (Maskell \& Malmberg, 1999). Não à toa, Amin (1999) propõe que as políticas de desenvolvimento territorial, baseadas na perspectiva institucional devem incentivar a formação de redes de associação e não de agentes individuais. As redes de associação, fundadas nas pluralidades de agentes e na negociação coletiva, são, elas mesmas, institucionalidades que criam novas normas (formais e informais) que respondem às instituições originárias de outras escalas.

O caso em estudo neste trabalho demonstra, de forma bastante clara, como as instituições definem, juntamente com outros fatores, a trajetória econômica e as perspectivas de desenvolvimento de um território. A abordagem segue a perspectiva esboçada nas linhas anteriores, ou seja, identifica algumas condicionantes insti- 
tucionais externas que vêm ditando o desenvolvimento recente do arranjo produtivo de petróleo e gás natural de Macaé, e as tentativas de base local para implantar uma rede de associação e consolidar um micro ambiente institucional que ajude a aumentar a competitividade das empresas locais.

\section{As condicionantes institucionais de origem externa e seu corolário na esfera local: a Lei do Petróleo de 1997 e as normas contratuais das corporações}

Os ambientes institucionais que governam a dinâmica econômica dos territórios são formados pela adaptação e assimilação, na esfera local, de um conjunto de institucionalidades originadas em outras escalas de origem. No contexto econômico contemporâneo, a forma como ocorre essa relação entre a lógica local e as pressões externas vai condicionar o modo como os territórios se inserem na globalização. O paradigma do desenvolvimento territorial, apesar da valorização dos aspectos endógenos dos territórios, não pode ser entendido fora do contexto de competição territorial a níveis internacionalizados. As disputas em torno da abertura dos mercados giram em torno da questão da exposição das bases produtivas nacionais (e locais) ao regime concorrencial atual, altamente inovador e incerto. Os novos espaços industriais, considerados grandes exemplos da "boa" inserção à globalização, construíram modos eficientes de reatividade às vicissitudes das conjunturas macroeconômicas.

A indústria de petróleo e gás natural é um dos setores da economia mais internacionalizados. O setor é dominado por uma série de grandes players globais, que não raro entram em conflito com os Estados sobre quem vai regular as regras do jogo setoriais. Devido ao grande poder de uso do espaço, os Estados e as corporações são, portanto, os principais agentes que normatizam os ambientes institucionais dos territórios produtivos formados pela atividade petrolífera.

No Brasil, segundo descreve Farias (2003), a regulação da indústria de petróleo e gás natural brasileira sempre foi motivo de embates entre correntes nacionalistas e segmentos liberais da sociedade. Até 1997, o nacionalismo, representado pelo monopólio do Estado na exploração e produção, foi a perspectiva dominante. Porém, com a "redemocratização" da política do país e devido ao quadro de profunda instabilidade macroeconômica no final da década de 80 , as correntes neoliberais ganharam grande espaço nas três primeiras eleições diretas para a presidência ${ }^{8}$. Durante o governo Fernando Henrique Cardoso foi realizada uma grande reforma nas diretrizes da política energética nacional, conhecida como Lei do Petróleo, devido às polêmicas geradas pelas mudanças impostas ao setor, símbolo magno do nacionalismo brasileiro. Em 1995, através de uma emenda constitucional, o governo quebrou o monopólio da Petrobras, abrindo a possibilidade de empresas privadas nacionais ou estrangeiras explorarem as reservas brasileiras. Em 1997, a reforma foi

8 No caso, em 1989, Collor de Mello, adotando as orientaçōes do Consenso de Washington, iniciou um profundo processo de desestatização da economia, continuado pelo seu vice, Itamar Franco (1992-1994) e consolidado nas duas administraçōes de Fernando Henrique Cardoso (1995-1998; 1999-2002). 
consolidada pela dita lei, que além de corroborar a participação do capital privado no segmento upstream, criou a Agência Nacional de Petróleo (ANP), responsável pela delimitação dos blocos exploratórios e pela regulação dos contratos de concessão. Até 2008, a ANP realizou 10 rodadas de licitação, em que foram leiloados 511 blocos exploratórios a 47 empresas nacionais e estrangeiras. É digno de nota que, não obstante o discurso que definia as estatais como símbolo da ineficiência, a Petrobras por conta de sua expertise de décadas de exploração no país tem arrematado, segundo Lopes Júnior (2007), cerca de metade dos blocos ofertados, contando ainda com uma alta taxa de sucesso nas prospecções.

Alguns efeitos da abertura do setor ao investimento privado foram logo observados. A mais evidente e propagandeada foi a enorme expansão da produção de petróleo e gás natural no país, a ponto de, em 2007, superar o consumo dos dois recursos no mercado interno. Muito em função do próprio crescimento da estatal brasileira, os valores em jogo no mercado de contratações de fornecedores foram bastante ampliados. Não à toa, no arranjo produtivo de petróleo e gás de Macaé, como foi demonstrado, houve um importante incremento no número de empresas fornecedoras instaladas no município e, por conseguinte, a expansão da oferta de empregos formais. $\mathrm{O}$ crescimento das demandas, no entanto, também atraiu interesses de empresas e organizações estrangeiras que, junto com as petroleiras, ingressaram no país. Um destaque deve ser dado ao apoio de organizações governamentais do Reino Unido (a Offshore Supply Office) e da Noruega (a INTSOK), que agregam empresas fornecedoras desses países, na implementação de políticas para conquistar fatias do mercado brasileiro.

Daí, concomitantemente à expansão do mercado de contratações no setor petrolífero, uma questão que logo se levantou era sobre a capacidade competitiva do parque nacional de fornecedores, que repentinamente foi exposta, com pouco suporte governamental, à competição internacional. Esse quadro foi agravado pelo fato de que algumas das operadoras estrangeiras que compraram concessões já tinham relações contratuais com fornecedoras de seus países de origem, o que significava uma vantagem para estas. Além disso, durante o governo de Fernando Henrique Cardoso, a junção de fatores desfavoráveis, no caso, a escassez de políticas que fortalecessem o parque fornecedor nacional, a política de contratações da Petrobras que privilegiava o menor preço e a política tributária desfavorável à produção nacional, resultou na transferência de recursos da estatal para outros países que, em geral, adotavam estratégias agressivas de atração de compras para seus parques industriais?.

Em resposta ao quadro de expansão dos investimentos e acirramento da competição, foram gestadas, no seio do parque fornecedor nacional, uma série de iniciativas e articulações com vistas ao fortalecimento das empresas fornecedoras sediadas no país. A iniciativa de maior monta foi a criação, em 1999, da Organização Nacional da Indústria de Petróleo (ONIP), que visa articular empresas petrolíferas

9 Um caso particularmente sintomático foi o fato da maior plataforma construída até então, a P 36, ter sido construída na Itália e no Canadá. 
fornecedoras de bens e serviços nacionais, agentes financeiros e órgãos governamentais com fins de promover o debate político e maximizar as oportunidades de ingresso do parque nacional de fornecedores de bens e serviços nos contratos das concessionárias. Além da ONIP, proliferaram-se pelo país várias organizações que vêm tentando institucionalizar redes de empresas a nível regional e local, dentre as quais a Rede Petro-BC, com sede em Macaé é uma das mais destacadas.

Em 2003, com o início da administração de Luis Inácio "Lula" da Silva, de caráter mais alinhado ao nacionalismo, o governo federal passou a promover políticas mais robustas de fortalecimento da indústria nacional. Logo no início do novo governo, a ANP modificou as regras dos contratos de concessão, adicionando a obrigatoriedade da adoção de conteúdo local nas encomendas de produtos e serviços, através do qual a operadora se compromete a garantir no mínimo 30\% dos contratos no mercado nacional. Através dessa norma, o governo intentou proteger as empresas do país, mas ao mesmo tempo, estimular a adoção de posturas mais competitivas no parque nacional. Outras iniciativas foram a criação do Programa de Mobilização da Indústria Nacional de Petróleo e Gás Natural (Promimp), cujo objetivo é a qualificação maciça de mão de obra especializada, e o CTPetro, que visa financiar pesquisas para o desenvolvimento de novas tecnologias para a cadeia produtiva.

O quadro exposto nas linhas acima foi fundamental para a ampliação do poder das corporações na criação e difusão das normas que demarcam as barreiras de entrada ao mercado de contratações. Como é sabido, nos setores em que a cadeia produtiva é desintegrada, as empresas âncoras se tornam as principais indutoras da otimização organizacional e tecnológica das terceirizadas, processo no qual a disputa pelos contratos adquire papel central. Destarte a abertura do setor, ao estimular a entrada de novas concorrentes, impôs o imperativo da constante renovação das empresas do parque fornecedor nacional, que em grande parte é reativo às demandas tecnológicas das players do setor no Brasil.

Em Macaé, a liderança normativa que norteia os padrões operacionais das empresas do arranjo produtivo pertence à Petrobras. Em 2008, segundo fontes da própria empresa, foram gerados mais de 45 mil empregos diretos na Bacia de Campos em função dos contratos terceirizados. No segundo semestre de 2007, os dispêndios da estatal em compra de produtos somaram mais de $\mathrm{R} \$ 880$ milhôes, sendo que no segmento de serviços, foram mais de $\mathrm{R} \$ 50$ bilhões gastos no mesmo ano. Assim, o referencial de inserção na cadeia produtiva passa, obrigatoriamente, pela estatal.

A rede de fornecedores da Petrobras é formada a partir do credenciamento das empresas candidatas em dois cadastros: o Cadastro Corporativo, mais exigente, destinado às demandas de fornecimento da empresa como um todo; os Registros Locais, de menor densidade, que servem para atender as demandas específicas de cada unidade operacional da petrolífera. Em um e outro, a Petrobras estabelece uma série de condiçôes que tentam normatizar o gerenciamento (técnico, social, ambiental), a capacidade tecnológica e logística e o desempenho econômico das fornecedoras. Sendo aprovadas, as empresas adquirem uma certidão de cadastro que as habilita a participarem das licitações da estatal. Há, ainda, a necessidade das 
fornecedoras manterem-se sempre de acordo com o estado da arte setorial, visto que os registros cadastrais possuem validade somente anual, o que garante à Petrobras a manutenção constante da eficiência de sua rede de terceirização.

A ação normativa da Petrobras na esfera local tem sido responsável por pelo menos três implicações com importante potencial para o desenvolvimento territorial. Em primeiro lugar, as exigências contratuais estimulam a difusão das normas operacionais pela cadeia produtiva de petróleo e gás e por setores afins. Segundo asseveraram alguns empresários, nas pesquisas de campo muitas vezes a estatal exige o cadastramento não só de suas próprias empresas, mas também de seus fornecedores, o que fortalece a inserção das empresas em cadeias produtivas mais eficientes e competitivas. Em segundo lugar, as normas contratuais podem se tornar a pedra fundamental para a internalização das competências setoriais ao território, através da qualificação constante das pequenas e médias empresas, organizaçôes de apoio e do mercado de trabalho local. Muitas ações vêm sendo desenvolvidas nesse sentido, em que organizações de apoio, empresas especializadas e órgãos governamentais promovem programas de qualificação de todo tipo, tendo como base as normas contratuais estabelecidas pela Petrobras e também por outras grandes contratantes da Bacia de Campos ${ }^{10}$. Terceiro, portar o certificado de cadastramento da Petrobras se tornou uma importante comprovação de eficiência operacional, o que facilita bastante a prospecção de novos contratos no mercado local e nacional. Isso a nível coletivo pode representar uma capacitação do arranjo produtivo para fornecer produtos e serviços não somente na Bacia de Campos, mas também em outros territórios produtivos constituídos pela indústria petrolífera ${ }^{11}$.

Portanto, essas duas poderosas forças normativas de origem externa formam, de modo conjugado, o ambiente institucional que tem estimulado reações a nível local que, em resposta aos desafios impostos, se constituem em boas oportunidades de aproveitamento das potencialidades engendradas pelas atividades de petróleo na Bacia de Campos. Uma das mais significativas, a criação da Rede Petro-BC, é o objeto em análise na próxima seção.

\section{Articulação local e o ambiente institucional: uma análise da Rede Petro-BC}

Possuindo a principal concentração de empresas do segmento upstream do Brasil, o município de Macaé refletiu de modo evidente as principais transformações ocorridas na indústria petrolífera nacional. Por isso, as condicionantes que operam no nível das instituições, como se intentou discutir na seção anterior, tornam-se matrizes fundamentais para o desenvolvimento econômico local. A quebra do monopólio em 1997 e a posterior expansão dos investimentos e das pressões competitivas, representaram uma tendência à concentração dos principais contratos nas mãos das

Para maiores detalhes, ver o trabalho de Fauré (2005).

11 Muito emblemática foi a fala da administradora de uma empresa de origem local: “(...) você ter um CRCC (Cadastro Corporativo) hoje é um diferencial no mercado. (...) o CRCC atesta qualidade e algumas empresas, como a Mendes Júnior, só podem comprar de empresas que têm o CRCC. Se você chegar e apresentar a sua empresa para um cliente e na hora dizer que tem o CRCC da Petrobras, todo mundo te olha diferente." (entrevista realizada em março de 2009) 
grandes empresas, que possuem uma relação apenas instrumental com o local. Às empresas sediadas na região, sobraram os segmentos menos intensivos em capital e tecnologia, quais sejam, dependentes das empresas de maior porte estrangeiras e nacionais. Portanto, as problemáticas impostas ao parque fornecedor nacional são ainda mais agudas na esfera local.

Assim, uma preocupação marcante para as empresas locais é não serem engolidas pela expansão setorial. Como asseverou um dos entrevistados durante as pesquisas de campo, uma das maiores dificuldades para a classe empresarial é acompanhar a rápida evolução das conjunturas da indústria petrolífera, que além das mudanças de ordem macroeconômica, tem no componente inovador uma de suas marcas centrais. Tal quadro é ainda agravado pela própria forma como o arranjo produtivo se constituiu em Macaé. Sendo até os anos de 1970 um típico município interiorano alicerçado na agropecuária e no comércio varejista, a cidade de Macaé foi "subvertida" por uma lógica econômica que se instaurou de modo alheio à dinâmica anterior. Neste sentido, as dificuldades de articulações existentes entre os atores locais devem-se, em parte, ao próprio estranhamento em relação às profundas transformações ocorridas no território. Mesmo após a consolidação do arranjo produtivo, muitos trabalhadores e empresários que durante a semana fazem uso da cidade, não raro evitam os finais de semana no município, despendendo parte de seus ganhos em outras cidades ${ }^{12}$.

Não obstante, as demandas econômicas presentes na cadeia produtiva de petróleo e gás natural trouxeram um novo elemento à cidade, que são justamente os fluxos mercantis e não mercantis existentes entre as diversas empresas que operam na Bacia de Campos. Conforme apontou Silvestre (2006), esses fluxos, que têm na proximidade geográfica um fator relevante, são importantes na criação de soluções tecnológicas para exploração e produção petrolífera, mesmo tratando-se das grandes empresas fornecedoras de bens e serviços. A partir do arranjo produtivo, Macaé tornou-se, portanto, um lugar de densas interações de diversos níveis entre os atores que estão inseridos no setor petrolífero. De certa forma, esta característica, que é ligada às próprias particularidades setoriais, é uma matéria-prima para a construção de projetos de desenvolvimento territorial. A questão a ser resolvida é que o quadro de desarticulação mencionado anteriormente é, de fato, um limitante na elaboração de tais projetos coletivos.

Apesar disso, alavancadas pelo mesmo processo que levou à criação de organizações articuladoras a nível nacional, em Macaé a partir do início dos anos 2000 começaram a se delinear algumas tentativas de construção de redes de empresas no município. A iniciativa mais exitosa até o momento é a Rede Petro-BC, que tem se tornado nos últimos anos um importante referencial, tanto no nível regional quanto na escala nacional, no tocante à estratégias de articulação interempresarial. Sua criação foi inspirada na Rede Petro-RS, surgida poucos anos antes, que ancorada na Secretaria de Ciência e Tecnologia do Rio Grande do Sul, tinha auxiliado

12 É bastante ilustrativo o fato de que os hotéis macaenses cobram diárias mais caras durante os dias "uteis" da semana do que aos sábados, domingos e feriados. 
de modo decisivo às empresas gaúchas conquistarem contratos de fornecimentos de várias empresas da cadeia produtiva de petróleo e gás no país. Em vários outros estados foram criadas organizações similares, porém atualmente, a experiência da Rede Petro-BC é a que tem norteado a ação das demais redes de empresas no setor.

A organização foi lançada oficialmente em 08 de outubro de 2003, alicerçada num acordo de cooperação técnica entre a Petrobras, o Sebrae-RJ, a Onip, a Firjan, a Acim e a Prefeitura Municipal de Macaé ${ }^{13}$, que são as organizações instituidoras da rede. Na cerimônia de abertura, cerca de 200 empresas assinaram o termo de adesão, porém em 2009 o número de associados era em torno de 80. A grande maioria são pequenas e médias empresas sediadas no próprio município ou na região de entorno, que em geral prestam serviços especializados ou ao comércio de produtos industriais. Em termos de gestão, a organização é dividida em dois departamentos principais: o Comitê Gestor, formado por 16 representantes de empresas e organizações de apoio, que é o fórum de discussão e tomada de decisões, e a Secretaria Executiva, responsável pela operacionalização das ações e pela gestão dos fluxos de informação.

O objetivo da Rede Petro-BC é justamente atuar sobre os impasses gerados pela baixa articulação entre as empresas e as organizaçôes de apoio. Em resumo, as principais finalidades da Rede Petro-BC são: (1) atender as demandas de bens, serviços e tecnologia na Bacia de Campos, de modo a ampliar a participação regional nas demandas do setor; (2) ampliar as oportunidades de negócios das empresas associadas a partir da promoção de relações qualificadas e da melhoria dos fluxos de informação intrarrede; (3) incentivar a prática da pesquisa aplicada na região e aproximar as empresas, as instituições de ensino e pesquisa da região e os órgãos de fomento; (4) incentivar a qualificação empresarial através da promoção de treinamentos, cursos e seminários; (5) promover estudos e análises técnicas sobre temas de interesse para o setor de petróleo e gás da Bacia de Campos.

A grande importância da organização é que se trata de uma importante inovação institucional ocorrida na esfera local, pois muitos elementos fundamentais para o desenvolvimento territorial, que até então estavam ausentes no arranjo produtivo, começam a ser delineados no âmbito da rede. É possível se verificar pelo menos quatro desses elementos, a saber, (1) o princípio fundador da articulação, que sustenta a própria existência da Rede Petro-BC; (2) a sincronização da proximidade relacional com a proximidade geográfica; (3) o estímulo e o apoio às empresas locais internalizarem as exigências normativas do setor, de modo a melhorar seus níveis de competitividade; (4) a tomada de posição da organização, enquanto fórum de governança de estratégias de consolidação do arranjo produtivo.

Em referência ao primeiro ponto, a Rede Petro-BC não é um ente jurídico formal, logo, legalmente a organização não existe. Sua existência, na prática, é derivada somente do compromisso firmado entre as organizações instituidoras através do

13 Para efeito de compreensão, as siglas citadas têm o seguinte significado: Sebrae-RJ, Serviço Brasileiro de Apoio às Micro, Pequenas e Médias Empresas - Seção Rio de Janeiro; Onip, Organização Nacional da Indústria de Petróleo; Firjan, Federação das Indústrias do Estado do Rio de Janeiro; Acim, Associação Comercial e Industrial de Macaé. 
convênio de cooperação técnica, que atribui as respectivas funções, que incluem, dentre outras, a cessão de locais para as reuniões, pagamento dos funcionários da Secretaria Executiva, representação jurídica, manutenção de equipamentos de tecnologia de informação, assistência a programas de qualificação e o repasse de informações estratégicas à rede, quando conveniente. Há ainda de se ressaltar que, juntamente com as organizações instituidoras, a Rede Petro-BC é sustentada pelo compromisso do empresariado local que, além de manter financeiramente a organização, tem sido fortemente representado no Comitê Gestor. Esta é uma característica que, em particular, é nova na região, visto que em quase todas as ações econômicas locais há um forte investimento das prefeituras. No caso da Rede Petro-BC, a prefeitura de Macaé tem importante participação, porém, não como âncora da organização. Foi em virtude desse modelo de gestão não burocrático e baseado em redes de associação, que a Rede Petro-BC se resguardou dos problemas advindos das mudanças de governo, como o ocorrido na organização gaúcha, que por estar ancorada em órgãos do governo estadual, perdeu efetividade com as reestruturações que normalmente ocorrem em novas administrações governamentais.

Quanto ao segundo ponto, o princípio da articulação é o fundamento que tem permitido a constituição de redes de associação que engendram a sincronização entre a proximidade relacional e a proximidade geográfica. Como visto, nem sempre estar próximo geograficamente significa intensificação dos laços relacionais. A junção entre as duas formas de proximidade é um dos passos fundamentais para a promoção do desenvolvimento territorial, o que em Macaé ainda é incipiente. A Rede Petro-BC tem representado um avanço no ambiente local, no que concerne ao estímulo à troca de informações entre as empresas, além de facilitar a criação de novos negócios. A organização tem tentado estimular os fluxos já existentes entre as empresas do arranjo produtivo, de modo a criar um ambiente de confiança diferenciado em relação às empresas não associadas. Somente entre as 16 empresas visitadas durante a pesquisa, foram citados 265 contatos, sendo que a maior parte foi qualificada como relações entre fornecedores e clientes, e alguns citaram a existência de parcerias e troca de informaçôes de mercado. Quanto ao grau de importância dos contatos, há uma tendência entre os respondentes de qualificá-los entre altíssima e alta importância. Isto seria óbvio entre as relações fornecedor-cliente, mas verificase que entre as empresas entrevistadas, existe uma valorização grande das parcerias e, principalmente, das trocas de informaçóes de mercado. As parcerias englobam, geralmente, prestação de serviços conjuntos ou indicação a possíveis clientes. As trocas de informações de mercado foram consideradas, pelos respondentes que citaram este tipo de interação, como uma importante estratégia para a antecipação de cenários do mercado petrolífero e elaboração da estratégia empresarial.

A partir desse quadro, a Rede Petro-BC se esforça para qualificar os fluxos relacionais. As principais ações se materializam através da organização de diversas reuniões durante o ano. Existem as reuniões do Comitê Gestor, que ocorrem mensalmente e, em que há sempre a avaliação conjunta das conjunturas setoriais e a definição das estratégias de ação para a rede. Trimestralmente ocorrem reuniões 
gerais, abertas ao público, que servem para discussão de temas de interesse do setor de petróleo e gás e também abrem um espaço privilegiado para encontros informais entre empresários, autoridades públicas, acadêmicos e visitantes em geral. Outra linha de trabalho adotada pela Rede Petro-BC é disponibilizar aos seus associados, a baixíssimo custo, informações estratégicas para novos contratos. Para tanto, a rede organiza, cerca de cinco ou seis vezes ao ano, rodadas de negócios com as principais contratantes da Bacia de Campos, incluindo a própria Petrobras (que no caso, é feita uma rodada em específico, denominada "Programa de Desenvolvimento de Fornecedores"). Em negociações fechadas, as contratantes apresentam à rede algumas de suas demandas, cuja disponibilidade de fornecedores qualificados é baixa. A organização disponibiliza a informação às associadas que, se dentro das normas exigidas, são apresentadas aos representantes das contratantes. No caso de não haver fornecedor qualificado no interior da Rede Petro-BC, a organização prospecta candidatos nas redes similares no país, abrindo o espaço para outras áreas do parque fornecedor nacional.

QUADro 3 Tipos de relacionamento identificados na Rede Petro-BC

\begin{tabular}{lr} 
Número de empresas entrevistadas & 16 \\
Número total de citações & 265 \\
Relaçōes fornecedor-cliente & 209 \\
Parcerias & 34 \\
Troca de informaçōes de mercado & 22 \\
\hline
\end{tabular}

FONTE VISITAS DE CAMPO.

QUADRO 4 Qualificação da importância de cada tipo de relacionamento pelos entrevistados

\begin{tabular}{l|cccc}
\hline GRAU DE IMPORTÂNCIA & ALtíssimo & ALto & MODERADo & BAIXo \\
\hline Cliente & $28,90 \%$ & $61,40 \%$ & $9,00 \%$ & $0,60 \%$ \\
Fornecedor & $4,70 \%$ & $51,20 \%$ & $39,50 \%$ & $4,70 \%$ \\
Parceria & $14,70 \%$ & $61,80 \%$ & $20,60 \%$ & $2,90 \%$ \\
Troca de informaçóes de mercado & $45,50 \%$ & $31,80 \%$ & $18,20 \%$ & $4,50 \%$ \\
\hline
\end{tabular}

FONTE VISITAS DE CAMPO.

O terceiro aspecto do papel institucional da Rede Petro-BC é seu posicionamento enquanto apoio intermediário entre as empresas locais e os padrões nor- 
mativos exigidos nos contratos de fornecimento das grandes empresas. Uma das últimas ações consideradas estratégicas pelo Comitê Gestor é o posicionamento da organização enquanto selo certificador para as empresas associadas, ou seja, a pretensão para o futuro é transformar a filiação na Rede Petro-BC numa credencial junto ao mercado petrolífero, do mesmo modo como funciona atualmente com o porte do CRCC da Petrobras. Para tanto, existe a perspectiva de aumento das exigências normativas para novas inserções e para a continuidade nos quadros associativos da rede. O novo padrão é possuir o credenciamento como fornecedor da Petrobras ou da ONIP, que são os dois principais referenciais do mercado.

Tal estratégia é particularmente interessante por dois motivos. O primeiro é que estimula de forma compulsória a qualificação das empresas locais, assim como torna ainda mais especializada o foco da organização, que é o apoio a empresas que sejam realmente fornecedoras do setor de petróleo e gás. Segundo, trata-se de uma ação que pode tanto aproveitar quanto retroalimentar o ambiente relacional gestado na Rede Petro-BC, já que entidades como o Sebrae-RJ, a Firjan e a Acim possuem tradição em implementar programas de qualificação e certificação a empresas e a recursos humanos. Além disso, os dois principais referenciais normativos do setor, a Petrobras e a Onip, possuem participação central na rede. Há, portanto, um forte potencial para a intensificação da cooperação entre essas organizações e as empresas associadas da Rede Petro-BC.

Finalmente, o quarto aspecto, a Rede Petro- $\mathrm{BC}$ vem consolidando um papel de governança com forte identidade territorial. Não é exagero dizer que o próprio sucesso da organização depende, em alto grau, da consolidação do arranjo produtivo localizado em Macaé como um território de relevo para o setor de petróleo e gás natural do país. A ação nesse sentido de maior substância é o posicionamento da rede como fórum de governança do projeto de implantação formal do Arranjo Produtivo Local Petróleo, Gás e Energia da Bacia de Campos (APL PGE BC), planejado a partir do convênio firmado em 2005 entre o SEBRAE Nacional e a Petrobras, para aumentar a competitividade das pequenas e médias empresas brasileiras que pertencem à cadeia produtiva de petróleo e gás natural. Através do projeto APL PGE BC, se pretende construir uma territorialidade caracterizada pela alta capacitação empresarial e tecnológica, que inclui um ambiente relacional e de negócios densificado, uma mentalidade empreendedora, socialmente responsável e ambientalmente sustentável e resultando numa maior participação no mercado de contratações das grandes empresas do setor.

Muitos dos objetivos apresentados pelo projeto APL PGE BC já estavam em gestação através da Rede Petro-BC, que por isso, se tornou uma dos eixos fundamentais para a implantação do projeto. Não à toa, a organização tem sido cada vez mais reconhecida na esfera regional como a principal representante das pequenas e médias empresas fornecedoras de bens e serviços, junto, tanto nas administrações públicas e às grandes empresas, apesar da rede contemplar uma percentagem pequena do tecido empresarial local. 
Antes de finalizar, cabe pontuar algumas dificuldades que foram observadas durante a pesquisa, que atuam como gargalos para a articulação local. A Rede PetroBC é o corolário da mudança institucional em curso na esfera local em resposta às pressões de origem externa. $\mathrm{O}$ ambiente institucional, no entanto, possui forte poder de inércia, como foi pioneiramente observado por Thorstein Veblen (1965). Apesar dos esforços em torno da articulação, a Rede Petro-BC replica em seu interior a série de gargalos encontrados no contexto mais amplo do arranjo produtivo. Verifica-se, ainda, muito individualismo e pouco envolvimento por parte de muitos associados, que por consequência tendem a ter uma postura mais negativa em relação ao que esperavam ao aderirem à organização. Muitos empresários esperam que a Secretaria Executiva e o Comitê Gestor levem as oportunidades de negócios até suas portas, quando na verdade, o objetivo é criar o ambiente relacional mais propício aos negócios. É evidente que se não há um envolvimento nesse sentido, haverá uma diminuição nos negócios feitos. O fato é agravado por dois problemas operacionais da organização, a saber: a existência de dois segmentos relacionais no interior da rede e as falhas no monitoramento e divulgação dos resultados positivos engendrados a partir da participação da rede. No primeiro caso, nota-se que os fluxos de informações entre os componentes do Comitê Gestor são muito mais densos do que dos demais, o que, é bom dizer, seria normal. O problema é que a assimetria é muito alta, o que gera certo sentimento de exclusão de parte do empresariado. $\mathrm{O}$ segundo caso, parte da sensação de imobilismo observado por alguns associados, pode ser tributado à invisibilidade de negócios que foram realizados a partir de alguma intermediação da Rede Petro-BC. O site da organização não é tão atualizado e dinâmico quanto seria desejável. É possível que a imagem da organização sofra alguma mudança positiva caso se adote métodos de monitoramento mais eficazes.

Fica demonstrado, portanto, os delineamentos gerais que direcionaram o ambiente institucional que governa o arranjo produtivo de petróleo e gás natural de Macaé. Uma questão que ficou em aberto e que merece maior aprofundamento é sobre a contradição existente entre os hábitos culturais estabelecidos e os imperativos, que tornam necessários o processo de mudança institucional. $\mathrm{O}$ ambiente da Rede Petro-BC é também um ótimo laboratório para o tema, porém, outras realidades existentes na esfera local podem servir como estudos de caso.

\section{Considerações finais}

A abordagem institucional oferece importantes ferramentas conceituais para compreender a influência das normas, das leis e das convenções culturais na estruturação e na evolução econômica dos territórios. Há, no entanto, ambiguidades teóricometodológicas que precisam ser melhor trabalhadas através da pesquisa empírica, meio pelo qual se pode avaliar a operacionalização das hipóteses conceituais.

No caso estudado do arranjo produtivo de petróleo e gás natural localizado em Macaé, foi verificado que os dois critérios metodológicos adotados, lembrando, a iden- 
tificação dos papéis representados pelos agentes na criação, difusão e adaptação das instituições e as diversas escalas que devem ser consideradas na análise dos ambientes institucionais, foram bastante relevantes para a problematização do caso em tela.

Destarte, fica demonstrado que os desafios e as potencialidades que demarcam a trajetória possível ao desenvolvimento local possuem sua origem, em parte, nas mudanças institucionais que marcaram o setor petrolífero brasileiro, a partir da abertura encetada pela Lei do Petróleo de 1997. A expansão do mercado de contratações de fornecimento e o acirramento das pressões competitivas são centrais para entender a lógica a que as empresas fornecedoras locais precisam se adaptar. Mas para isso, é necessário empreender mudanças institucionais na esfera local, que ainda possui problemas importantes de falta de coordenação coletiva. A Rede Petro$B C$, porém, é uma iniciativa relativamente recente que tem realizado um trabalho seminal de melhoria dos ambientes relacionais, aproveitando-se da proximidade geográfica, o que, em última análise, representa uma importante ancoragem da organização na territorialidade local.

Espera-se que, com este trabalho, possa-se contribuir para outros estudos das regióes petrolíferas no Brasil, principalmente após a descoberta das gigantescas jazidas na camada Pré-Sal da costa brasileira, que incentivou a proposta de um novo marco regulatório, de caráter mais nacionalista. Se bem sucedida, cabe retomar os estudos para avaliar como essas novas mudanças normativas impactarão as realidades locais. @EURE

\section{Referências bibliográficas}

Amin, A. (1999). An institutionalist perspective on regional economic development. International Journal of Urban and Regional Research, 23(2), 365-378. doi: 10.1111/1468-2427.00201

Amin, A. (2001). Moving on: Institutionalism in economic geography. Environment and Planning A., 33(7), 237-1241.

Barral Neto, J. F. \& Silva Neto, R. (2006) Reestruturação produtiva e interiorização econômica: uma nova dinâmica para a Região Norte Fluminense. XV Encontro Nacional de Estudos Populacionais. Caxambu.

Batista, I. L. (2006). Redes produtivas no Sul Fluminense. Rio de Janeiro, tese de doutorado em Geografia, Universidade Federal do Rio de Janeiro.

Borba, R. C. \& Silva Neto, R. (2008). Impactos das atividades offshore de exploração e produção de petróleo nas cidades: um estudo comparativo entre Macaé (Brasil), Ciudade Del Carmen (México) e Aberdeen (Reino Unido). X Seminário Internacional de la RII, Santiago de Querétalo, México.

Dias da Silva, R. (2004). Rio de Janeiro: crescimento, transformações e sua importância para a economia nacional (1930-2000). Campinas, dissertação de mestrado em desenvolvimento econômico, Instituto de Economia, Universidade Estadual de Campinas.

Farias, P. (2003). Nacionalismo e participação popular na campanha “O Petróleo é Nosso". En R. Piquet (Ed.), Petróleo, royalties e região (pp. 13-37). Rio de Janeiro: Garamond.

Fauré, Y. (2005). Internalizar as oportunidades do petróleo e diversificar a economia municipal. En Y. 
Fauré \& L. Hasenclever (Eds.), O desenvolvimento local no estado do Rio de Janeiro: estudos avançados nas realidades municipais (pp. 215-322). Rio de Janeiro: E-Papers.

Filippi, M. \& Torre, A. (2002). Organizações e instituições locais: como ativar a proximidade geográfica por meio de projetos coletivos? Cadernos IPPUR, 15(2), 81-101.

Hayter, R. (2004). Economic geography as dissenting institutionalism: The embeddedness, evolution and differentiation of regions. Geografiska Annaler, 86(2), 95-115. http://www.jstor.org/ stable/3554294

Lopes Júnior, F. (2004). Análise do planejamento estratégico e ações de mercado das empresas de petróleo face à abertura de mercado. Niterói, dissertação de mestrado em engenharia de produção, Universidade Federal Fluminense.

Martin, R. (2000). The institutional aproaches in economic geography. En E. Shepard \& T. Barnes (Eds.), A companion to economic geography (pp. 77-94). Londres: Blackwell.

Maskell, P. \& Malmberg, A. (1999). Localised learning and industrial competitiveness. Cambridge Journal of Economics, 23(2), 167-185. doi: 10.1093/cje/23.2.167

Nascimento, R. (1999). O impacto da Petrobras no município de Macaé: uma análise das mudanças urbanas e na estrutura do emprego. Rio de Janeiro, dissertação de mestrado em planejamento urbano e regional, Universidade Federal do Rio de Janeiro.

Natal, J. (2005). O Estado do Rio de Janeiro pós-1995: dinâmica econômica, rede urbana e questão social. Rio de Janeiro: Pubblicati.

North, D. (1990). Institutions, institutional change and economic performance. Nueva York: Cambridge University Press.

Nunes, E., Nogueira, A., Costa, C. \& Andrade Ribeiro, L. (2007). Agências reguladoras e reforma do Estado no Brasil: inovação e continuidade no sistema político-institucional. Rio de Janeiro: Garamond.

Oliveira, F. G. (2003). Reestruturação produtiva e regionalização da economia no território fluminense. São Paulo, tese de doutorado em geografia humana, Universidade de São Paulo.

Oliveira, M. B. L. (2005). Redes de cooperação de micro e pequenas empresas: um estudo das empresas da cadeia de petróleo e gás do município de Macaé-RJ. Niterói, dissertação de mestrado em sistema de gestão, Universidade Federal Fluminense.

Piquet, R. \& Oliveira, E. L. (2007). Empresas e empresários do Norte Fluminense: uma análise qualitativa. Em R. Piquet \& R. Serra (Eds.), Petróleo e regiäo no Brasil: o desafio da abundância (pp. 267-288). Rio de Janeiro: Garamond.

Putnam, R. (2000). Comunidade e democracia na Itália Moderna. Rio de Janeiro: Editora FGV.

Rallet, A. (2002). Economia da proximidade: em direção a um balanço. Cadernos IPPUR, 15(2), 81-101.

Rede Petro-BC. (2005). Acordo de cooperação técnica. Macaé.

Rede Petro-BC. (2008). Relatório final da consultoria à Rede Petro-BC. Macaé.

Santos, F., Crocco, M. \& Lemos, M. (2006). Aglomerações produtivas em espaços periféricos: uma abordagem regional. En Y. Fauré, L. Hasenclever \& R. Lopes (Eds), Caleidoscópio do desenvolvimento local no Brasil: diversidade das abordagens e das experiências (pp. 375-407). Rio de Janeiro: IE/UFRJ e IRD/França.

Santos, M. (2004). A natureza do espaço: técnica e tempo, razão e emoção. $4^{a}$ ed. São Paulo: Edusp.

Scott, A. (1998). The new industrial spaces. Londres: Pion. 
Silvestre, B. (2006). Aglomeração industrial de petróleo e gás do norte fluminense: conexões de conhecimento e posturas tecnológicas das firmas. Rio de Janeiro, tese de doutorado em engenharia de produção, Pontifícia Universidade Católica do Rio de Janeiro.

Storper, M. (1997). The Regional World: Territorial development in a global economy. Nueva York: The Guilford Press.

Veblen, T. (1965). A teoria da classe ociosa: um estudo econômico das instituiçôes. São Paulo: Livraria Pioneira Editora.

Veltz, P. (1999). Mundialización, ciudades y territórios. Barcelona: Ariel Geografia.

\section{Sites}

http://www.anp.gov.br

http://www.clickmacae.com.br

http://www.mte.gov.br

http://www.petrobras.com.br

http://www.redepetro-bc.com.br 